\title{
Efektivitas Terapi Psiko Spiritual (Dzikir Dengan Nafas Dalam) Terhadap Penurunan Tingkat Kecemasan Pada Pasien Tuberkulosis Paru Dengan Terapi Obat
}

\author{
${ }^{1}$ Muhammad Amrullah*, ${ }^{2}$ Muhammad Rizam Umami, ${ }^{3}$ Alon Ekawati \\ ${ }^{1,2,3}$ Universitas Qamarul Huda Badaruddin Fakultas Kesehatan \\ *Email : mrizamumami21@gmail.com
}

Kata kunci:

Spiritual,

Kecemasan,

Tuberkulosis

Keywords:

Spiritual, Anxiety,

Tuberculosis

Tanggal dikirim:

26 Februari 2021

Tanggal direvisi:

23 Maret 2021

Tanggal diterima:

5 April 2021

DOI Artikel:

10.33862/citradelim

a.v5i1.212

Halaman: 6-10

\begin{abstract}
Abstrak
Tuberkulosis adalah penyakit infeksi menular yang dapat menyerang berbagai organ terutama paruparu, terapi yang digunakan pada pasien TB yaitu dengan follow up obat anti tuberculosis (OAT). Namun penggunaan terapi OAT tersebut dapat menimbulkan banyak efek samping, seperti gangguan pencernaan, nyeri sendi, gangguan psikis, visual dan syaraf, dimana efek samping tersebut dapat menimbulkan kecemasan. Salah satu terapi yang dapat di aplikasikan untuk menurunkan tingkat kecemasan yaitu terapi psiko spiritual dalam bentuk dzikir diikuti dengan teknik nafas dalam. Tujuan Penelitian adalah untuk mengetahui bagaimana efektivitas terapi psiko spiritual dzikir dengan nafas dalam terhadap penurunan tingkat kecemasan pada pasien Tuberculosis Paru. Penelitian ini dilakukan pada tanggal 15-19 September 2020. Penelitian ini menggunakan metode Pre Eksperimental dengan menggunakan pendekatan One Group Pre-Post test desain. Teknik pengambilan sample dengan non probability sampling yaitu accidental samplingyang sesuai dengan kriteria inklusi dan eksklusi yang ditentukan oleh peneliti. Populasi berjumlah 28 orang dengan jumlah sample sebanyak 21 orang dengan kecemasan. Analisa data menggunakan uji t-test. Hasil uji statistik t-test diperoleh efektifitas terapi psiko spiritual terhadap penurunan tingkat kecemasan pada pasien Tuberculosis Paru dengan terapi OAT $p$ value $=0,001$. Dapat disimpulkan bahwa dalam penelitian ini terdapat pengaruh terapi psiko spiritual terhadap penurunan tingkat kecemasan pada pasien Tuberculosis paru dengan terapi OAT.
\end{abstract}

\section{The Effectiveness of Psycho-Spiritual Therapy (Dzikir With Deep Breath) on Decreasing Anxiety Levels in Pulmonary Tuberculosis Patients with Drug Therapy}

\section{Abstract}

Tuberculosis is an infectious disease caused by the acid resistant bacteria Mycobacterium tuberculosis, a therapy that can be used to cure this disease is by distributing anti-tuberculosis drugs. However, this OAT therapy can cause many side effects, where these side effects can cause harm. One of the therapies that can be applied to lower notes is psycho-spiritual therapy in the form of dhikr followed by deep breathing techniques. The aim of the study was to measure the effectiveness of the psycho-spiritual dhikr therapy with breath in fighting the decline in pulmonary tuberculosis patients. This research was conducted on 15-19 September 2020. This study used a Pre-Experimental method using the One Group Pre-Post test design approach. The sampling technique used non-probability sampling, namely incidental sampling. The population of artifacts was 28 people with a total sample size of 21 people. Data analysis using t-test. The results of the t-test statistical test showed that the effectiveness of psycho-spiritual therapy in reducing the reduction rate in pulmonary tuberculosis with OAT therapy $\mathrm{p}$ value $=0.001$. There is an effect of psycho-spiritual therapy on reducing levels in pulmonary tuberculosis patients with OAT therapy. 


\section{PENDAHULUAN}

Kesehatan adalah hak asasi manusia yang wajib dilindungi dan diperhatikan oleh pemerintah. Menurut Hendrick L. Blum derajat kesehatan masyarakat sangat dipengaruhi oleh empat faktor yaitu factor perilaku, faktor lingkungan, faktor keturunan dan faktor pelayanan kesehatan, dari keempat factor tersebut yang pengaruhnya cukup besar adalah faktor perilaku dan diikuti oleh pengaruh factor lingkungan, setelah itu faktor pelayanan kesehatan, dan yang terakhir faktor keturunan. Keempat faktor di atas sangat berhubungan dan saling mempengaruhi (Syukra dan Sriani, 2015).

Penyakit yang timbul karena faktor lingkungan salah satunya adalah penyakit tuberkulosis (TB). Tuberkulosis (TB) adalah penyakit menular yang disebabkan oleh kuman basil tahan asam (BTA) yaitu Mycobacterium tuberculosis. Kuman ini menyebar dari satu orang ke orang lain melalui udara. Sumber penularan adalah pasien TB dengan BTA positif. Infeksi akan terjadi ketika orang lain menghirup udara yang mengandung percikan dahak infeksius tersebut (Kemenkes RI, 2014).

Salah satu terapi yang digunakan untuk pengobatan Tuberkulosis yaitu dengan terapi Obat Anti Tuberkulosis. Pasien TB dengan terapi OAT harus menjalani pengobatan minimal $9-26$ bulan, akibat kontiunitas pengobatan yang dijalani tersebut dapat menimbulkan banyak efek samping, efek samping yang dapat di timbulkan seperti rasa cemas, perasaan tidak tenang, gangguan pencernaan, lemas, mual muntah, dan nyeri sendi (Depkes RI, 2012).

Pada dasarnya, kecemasan merupakan hal wajar yang pernah dialami oleh setiap manusia. Kecemasan sudah dianggap sebagai bagian dari kehidupan sehari-hari. Kecemasan adalah suatu perasaan yang sifatnya umum, dimana seseorang merasa ketakutan atau kehilangan kepercayaan diri yang tidak jelas asal maupun wujudnya. Kecemasan merupakan sesuatu yang menimpa hampir setiap orang pada waktu tertentu dalam kehidupannya. Kecemasan merupakan reaksi normal terhadap situasi yang sangat menekan kehidupan seseorang. Kecemasan biasa muncul sendiri atau bergabung dengan gejala-gejala lain dari berbagai gangguan emosi (Hawari, D.2012).
Tahir dan Angreani (2017), menyatakan bahwa terapi yang digunakan untuk menurunkan tingkat kecemasan yaitu dengan berdzikir, karena dapat membantu menurunkan kecemasan pada pasien yang mempunyai fikiran negatif terhadap tindakan pembedahan.

Banyak terapi spiritual yang bisa di aplikasikan terhadap penanganan cemassalah satunya yaitu terapi psiko spiritual dzikir dengan nafas dalam.

Berdasarkan hasil studi pendahuluan yang di lakukan oleh peneliti, di peroleh dari 9 pasien yang peneliti temukan di RSUD Praya tanggal 25 Juni 2020, di peroleh informasi bahwa 9 pasien tersebut mengatakan bahwa mereka merasa cemas karena terapi OAT yang di berikan memiliki efek samping yang beragam seperti rasa cemas, perasaan tidak tenang, gangguan pencernaan, lemas, mual, muntah, dan nyeri sendi.

Untuk itu peneliti tertarik untuk meneliti efektivitas terapi psiko spiritual dzikir dengan nafas dalam terhadap penurunan tingkat kecemasan pada pasien TB dengan terapi OAT. Karena ketika pasien sudah bisa mengambil langkah terapi yang dapat menurunkan tingkat kecemasan pada penyakit yang di derita, maka kemungkinan besar pasien bisa mengatasi kecemasan apabila penyakit yang di deritanya tidak bisa disembuhkan (Sumarsih, 2019).

\section{METODE}

Jenis penelitian ini adalah penelitian kuantitatif. Penelitian ini dilaksanakan pada bulan September 2020. Tempat penelitian di RSUD Praya.

Populasi penelitian ini adalah semua pasien Tuberculosis Paru di RSUD Praya yang berjumlah 28 orang. Kemudian setelah dilakukan skrining menggunakan teknik Himilton Anxiety Rating Scale (HARS), didapatkan sampel pada penelitian ini berjumlah 21 orang yang mengalami kecemasan dikarenakan terapi OAT yang dijalani. Dengan pembagian skor tingkat kecemasan sebagai berikut :
$<14$ : Tidak ada kecemasan
14-20 : Kecemasan ringan
21-27 : Kecemasan sedang
28-41 : Kecemasan Berat
42-56 :Kecemasan Berat Sekali

http://jurnalilmiah.stikescitradelima.ac.id/index.php/JI Vol. 5 No. 1 Juli 2021 
Teknik pengambilan sampel dengan non probability sampling yaitu accidental sampling, dengan kriteria inklusi, yaitu:

a. Pasien TB paru yang mengalami kecemasan dengan terapi OAT dan bersedia menjadi responden dan kooperatif.

b. Pasien TB paru yang mengalami kecemasan dengan terapi OAT yang mampu berkomunikasi dengan baik dan benar, dan beragama islam.

Kemudian kriteria eksklusi dari dari penelitian ini yaitu :

a. Pasien TB paru tetapi tidak mengalami kecemasan dengan terapi OAT, tidak berada ditempat penelitian dan yang tidak bersedia menjadi responden dan kooperatif.

b. Pasien TB paru yang tidak mampu berkomunikasi dengan baik dan benar, dan tidak beragama islam.

HASIL DAN PEMBAHASAN

Tabel 1. Distribusi tingkat kecemasan sebelum melakukan dzikir dengan nafas dalam.

\begin{tabular}{clcc}
\hline No & Tingkat Kecemasan & Jumlah & Persentase \\
\hline 1 & Tidak ada Kecemasan & 0 & $0 \%$ \\
2 & Kecemasan Ringan & 0 & $0 \%$ \\
3 & Kecemasan Sedang & 9 & $42,9 \%$ \\
4 & Kecemasan Berat & 12 & $57,1 \%$ \\
5 & Kecemasan Berat Sekali & 0 & $0 \%$ \\
\hline \multicolumn{2}{c}{ Total } & $\mathbf{2 1}$ & $\mathbf{1 0 0 \%}$ \\
\hline
\end{tabular}

Berdasarkan tabel 1. dapat ditunjukkan bahwa tingkat kecemasan pada pasien TB Paru sebelum melakukan terapi dzikir nafas dalam yang tertinggi adalah kecemasan berat sebanyak 12 responden (57,1\%), dan terendah adalah kecemasan sedang 9 responden $(42,9 \%)$.

Tabel 2. Distribusi tingkat kecemasan setelah melakukan dzikir dengan nafas dalam.

\begin{tabular}{clcc}
\hline No. & Tingkat Kecemasan & Jumlah & Persentase \\
\hline 1 & Tidak ada Kecemasan & 0 & $0 \%$ \\
2 & Kecemasan Ringan & 14 & $66,7 \%$ \\
3 & Kecemasan Sedang & 7 & $33,3 \%$ \\
4 & Kecemasan Berat & 0 & $\%$ \\
5 & Kecemasan Berat Sekali & 0 & $0 \%$ \\
\hline \multicolumn{2}{c}{ Total } & $\mathbf{2 1}$ & $\mathbf{1 0 0 \%}$ \\
\hline
\end{tabular}

Berdasarkan tabel 2. dapat ditunjukkan bahwa tingkat kecemasan pada pasien TB Paru setelah melakukan terapi dzikir nafas dalam yang tertinggi adalah kecemasan ringan sebanyak 14 responden $(66,7 \%)$, dan terendah adalah kecemasan sedang 7 responden $(33,3 \%)$.

Tabel 3. Distribusi Efektivitas terapi psiko spiritual (dzikir dengannafas dalam) terhadap penurunan tingkat kecemasan

\begin{tabular}{ccc}
\hline & \multicolumn{2}{c}{ Skor Kecemasan } \\
\cline { 2 - 3 } No. Res & Pre Test & Post Test \\
\hline 1 & 35 & 21 \\
2 & 39 & 26 \\
3 & 34 & 25 \\
4 & 29 & 20 \\
5 & 28 & 14 \\
6 & 36 & 21 \\
7 & 28 & 22 \\
8 & 24 & 17 \\
9 & 27 & 20 \\
10 & 31 & 21 \\
11 & 24 & 19 \\
12 & 38 & 19 \\
13 & 27 & 17 \\
14 & 28 & 15 \\
15 & 35 & 22 \\
16 & 27 & 18 \\
17 & 22 & 14 \\
18 & 32 & 21 \\
19 & 25 & 18 \\
20 & 30 & 21 \\
21 & 26 & 16 \\
\hline Mean & $\mathbf{3 . 5 7}$ & $\mathbf{2 . 3 3}$ \\
SD & $\mathbf{5 0 7}$ & $\mathbf{4 8 3}$ \\
\hline
\end{tabular}

Berdasarkan table 3. diatas adalah skor Hasil Tingkat Kecemasan pada pasien TB Paru sebelum dan sesudah dilakukan terapi psiko spiritual (dzikir dengan nafas dalam) di RSUD Praya.

Tabel 4. Data Hasil Uji t-Test

\begin{tabular}{ccc}
\hline T & df & Sig. (2-tailed) \\
\hline Mean & $\begin{array}{c}\text { Std. Deviation } \\
\text { Lower }\end{array}$ & $\begin{array}{c}\text { Std. Error Mean } \\
\text { Upper }\end{array}$ \\
Upper & $\mathbf{2 0}$ & $\mathbf{. 0 0 0}$ \\
\hline $\mathbf{1 3 . 0 0 0}$ & &
\end{tabular}

Berdasarkan hasil perhitungan SPSS diperoleh hasil t-hitung 13.000 yang dikonsultasikan dengan ttabel dengan tingkat kemaknaan 0.05 dan d.b $=20$ didapatkan t-tabel yaitu sebesar .000 atau t-hitung

http://jurnalilmiah.stikescitradelima.ac.id/index.php/JI Vol. 5 No. 1 Juli 2021 
lebih besar dari t-tabel (13.000>.000) sehingga Ho ditolak dan Ha diterima, artinya ada efektivitas terapi psiko spiritual dzikir dengan nafas dalam terhadap penurunan tingkat kecemasan pada pasien Tuberkulosis Paru dengan terapi OAT di ruang Rawat Inap RSUD Praya tahun 2020.

\section{Pembahasan}

Efektivitas terapi psiko spiritual dzikir dengan nafas dalam terhadap penurunan tingkat kecemasan pada pasien dengan terapi OAT.

Salah satu terapi yang dapat digunakan untuk menurunkan tingkat kecemasan yaitu terapi spiritual. Terapi spiritual sangat diperlukan karena sesungguhnya gangguan fisik maupun psikis disebabkan oleh faktor materi-biologis maupun faktor spiritual. Oleh karena itu, suatu penyakit harus disembuhkan berdasarkan dari faktor penyebabnya. Terapi spiritual bisa dilakukan dengan ruqyah, zikir, bertaubat, bertawakal, dan berdo'a agar disembuhkan dari penyakit (Rusydi,2015).

Dalam penelitian ini peneliti menggunakan terapi spiritual yaitu psiko spiritual dalam bentuk dzikir dengan Teknik nafas dalam, yang dilakukan selama 5 sampai 15 menit sebanyak 2 kali sehari, dengan ucapan "LaaIlaahaIllallah". Hal ini sesuai dengan penelitian yang dilakukan oleh Tahir dan Angreani (2017), yang menemukan terapi yang dapat digunakan untuk menurunkan tingkat kecemasan yaitu dengan berdzikir, karena dapat membantu menurunkan kecemasan pada pasien yang mempunyai fikiran negatif terhadap tindakan pembedahan.

Kecemasan merupakan hal wajar yang pernah dialami oleh setiap manusia sebagai bagian dari kehidupan sehari-hari. Kecemasan merupakan suatu perasaan yang sifatnya umum, dimana seseorang merasa ketakutan atau kehilangan kepercayaan diri yang tidak jelas asal maupun wujudnya yang menimpa hampir setiap orang pada waktu tertentu dalam kehidupannya. Kecemasan merupakan reaksi normal terhadap situasi yang sangat menekan kehidupan seseorang, kecemasan biasa muncul sendiri atau bergabung dengan gejala-gejala lain dari berbagai gangguan emosi (Hawari, D. 2012).
Spilberger (Annisa \& Ifdil, 2016) menjelaskan kecemasan dalam dua bentuk yaitu : trait anxiety dan state anxiety. Trait anxiety merupakan adanya rasa khawatir dan terancam yang menghinggapi diri seseorang terhadap kondisi yang sebenarnya tidak berbahaya dan belum tentu terjadi. Kecemasan ini disebabkan oleh kepribadian individu yang memang memiliki potensi cemas dibandingkan dengan individu yang lainnya, biasanya terjadi pada seseorang yang over thinking sehingga menyebabkan ia memiliki pikiran yang tidak rasional.Sedangkan state anxiety merupakan kondisi emosional dan keadaan sementara pada diri individu dengan adanya perasaan tegang dan khawatir yang dirasakan secara sadar serta bersifat subjektif.

Berdasarkan tabel 1. Dapat diketahui jumlah responden sebelum diberikan terapi terbanyak adalah tingkat kecemasan berat yaitu sebanyak 12 responden $(57,1 \%)$. Dampak yang ditimbulkan setiap pasien berbeda-beda tergantung dari tingkat kecemasan yang dirasakan oleh pasiensaatmenjalani follow up OAT. Perbedaan respon yang diberikan terhadap kecemasan yang dirasakan oleh pasien dipengaruhi oleh banyak faktor, diantaranya adalah faktor usia, dan pendidikan.

Berdasarkan tabel 2. dapat diketahui bahwa setelah diberikan terapi psiko spiritual dzikir dengan nafas dalam dari 21 responden yang memiliki tingkat kecemasan tertinggi dalah kecemasan ringan yaitu sebanyak 14 responden $(66,7 \%)$ dan tingkat kecemasan paling sedikit adalah kecemasan sedang yaitu 7 responden $(33,3 \%)$.

Berdasarkan hasil uji statistik t-test diperoleh efektivitas terapi psiko spiritual dzikir dengan nafas dalam terhadap penurunan tingkat kecemasan pada pasien Tuberkulosis Paru dengan terapi OAT dengan $p$ value $=0,001$ yang berarti nilai $p$ value $<0,05$ artinya Ho ditolak dan Ha diterima. Hal ini menunjukkan hasil penelitian yang dilakukan di RSUD Praya setelah dilakukan terapi psikospiritual dalam bentuk dzikir dengan nafas dalam didapatkan pengaruh yang signifikan untuk menurunkan tingkat kecemasan pada pasien tuberkulosis paru dengan terapi

OAT.

http://jurnalilmiah.stikescitradelima.ac.id/index.php/JI Vol. 5 No. 1 Juli 2021 
Hal ini juga didukung oleh hasil penelitian dari Anggraini \& Subandi (2014) yang menemukan bahwa ada pengaruh terapi relaksasi dzikir untuk menurunkan stres pada penderita hipertensi esensial, kemudian penelitian Nursatriati (2014) yang menemukan bahwa ada pengaruh dzikir terhadap penurunan tingkat kecemasan pada pasien pra operasi seksio sesarea.

\section{SIMPULAN}

Terapi psiko spiritual dapat menurunkan tingkat kecemasan karena dapat memberikan ketenangan dan rasa nyaman dalam diri seseorang. Pada penelitian ini didapatkan hasil yang signifikan setelah dilakukan terapi psiko spiritual dzikir dengan nafas dalam terhadap penurunan tingkat kecemasan pada pasien tuberkulosis paru di RSUD Praya tahun 2020. Bentuk terapi spiritual bisa seperti solat, dzikir, berdo'a, puasa, membaca al-qur'an, meditasi dan lain sebagainya sesuai dengan ketentuan yang sudah ditetapkan oleh agama.

\section{SARAN}

Berdasarkan data hasil penelitian yang dilakukan oleh peneliti diharapkan untuk dijadikan bahan pertimbangan untuk memberikan dukungan spiritual pada pasien tuberkulosis paru yang mengalami kecemasan karena terapi OAT maupun yang tidak menjalani follow up terapi OAT. Bagi peneliti selanjutnya dapat menggunakan variablevariabel lain yang dapat mempengaruhi kondisi psikologis dari pasien dengan kecemasan, jumlah responden yang lebih besar, area penelitian lebih luas dan waktu yang lebih panjang.

\section{DAFTAR PUSTAKA}

Anggraini dan Subandi (2014) Pengaruh Terapi Relaksasi Zikir Untuk Menurunkan Stres Pada Penderita Hipertensi Esensial.

Annisa dan Ifdil, (2016) Konsep Kecemasan (Anxiety) pada Lanjut Usia (Lansia). Volume 5 | Number 2 | June 2016.

Depkes RI, (2012) Pedoman Nasional Penanggulangan Tuberkulosis. Cetakan Kedua. Jakarta: Bakti Husada
Hawari, D (2012) Manajemen stres, cemas, dan depresi. Ed 1. Cetakan 4. FKUI, Jakarta

Kemenkes RI, (2014) Pedoman Nasional pengendalian Tuberkulosis, Kemenkes RI, Jakarta

Norman and Matthew. (2005) "Hamilton Anxiety Rating Scale (HAM-A)". Atlanta: Psychiatric Associates of Atlanta, LLC. Online pada www.atlantapsychiatry.com diakses November 2005.

Nursalam, (2013) Konsep dan Penerapan Metodologi Penelitian Ilmu Keperawatan.

Nursatriati (2014) Pengaruh dzikir terhadap penurunan tingkat kecemasan pada pasien pra operasi seksio sesarea (Suatu Penelitian di Ruang Kebidanan RSUD. Prof. Dr. Hi. Aloei Saboe Kota Gorontalo).

Journal Vol 3, No 1 (2015) : Prodi S1 Kesehatan Masyarakat, Periode Februari 2015, tersedia dalam http://kim.ung.ac.id/, diakses 11 Januari 2016.

Rusydi, (2015) Kecemasan dan Psikoterapi Spiritual Islam. Istana Publishing. Cetakan pertama, 2015.

Sugiyono, (2010) Statistika Untuk Penelitian. Bandung: Alfabeta.

Sugiyono, (2013) Metode penelitian kuantitatif, kualitatif \& R\&D. Bandung : Alfabeta

Syukra, dan Sriani, (2015) Buku Ajar Ilmu KesehatanMasyarakat.[e-book]

Deepublish.https://www.google.com/search? tbo=p\&tbm=bks\&q=isbn:6022808081 sitasi 10 Agustus 2016].

Tahir dan Angreani, (2017) Pengaruh dzikir terhadap kecemasan pada pasien pre operasi. Jurnal ilmiah kesehatan pencerah vol.6.No.1

Tri Sumarsih, (2019) Pengaruh Relaksasi Spiritual terhadap Perubahan Tingkat Ansietas dan Stres Pasien Tuberkulosis Paru di RS PKU Muhammadiyah Sruweng.

WHO, (2006) Tuberculosis. New York: WHO Media Centre; 2006.

http://jurnalilmiah.stikescitradelima.ac.id/index.php/JI Vol. 5 No. 1 Juli 2021 